\title{
In situ feeding behavior of the copepod Temora longicornis: effects of seasonal changes in chlorophyll size fractions and female size
}

\author{
Hans G. Dam*, William T. Peterson** \\ Marine Sciences Research Center, State University of New York, Stony Brook, New York 11794-5000, USA
}

\begin{abstract}
We estimated in situ ingestion rates of females of the calanoid copepod Temora longicornis in Long Island Sound, New York, USA, at roughly weekly intervals, between February and August from 1985 to 1987 using the gut fluorescence technique. Variability in gut pigment content (GPC) and ingestion rates (IR) was examined in relation to changes in the concentration of total chlorophyll and of chlorophyll in the $>20 \mu \mathrm{m}$ size fractions, and changes in body size. Correlations of GPC and IR with chlorophyll concentration were highest for the $>20 \mu \mathrm{m}$ size fraction and lowest for total chlorophyll. Saturation of GPC and IR was apparent only when phytoplankton $>10 \mu \mathrm{m}$ or $>20 \mu \mathrm{m}$ was considered as available food. These results lend support to the notion that the degree to which herbivorous coastal copepods are food-limited may be strongly dependent on the structure of the phytoplankton assemblage. Prosome length of female $T$ longicornis decreased by almost a factor of 2 , and dry weight by a factor of 4, from February to August. Correlations between weight-specific GPC, weight-specific IR and chlorophyll concentration in all size fractions were poorer than in the cases of GPC and IR on a per individual basis. However, a multivariate regression analysis indicated that most of the variance in GPC and IR was explained by the different size fractions of chlorophyll, not body weight. Therefore, the use of weight-specific indices may not always be justified even when variation in body size is pronounced. We suggest that multivariate analysis or other statistical techniques be employed, instead of weightspecific indices, when body size may be a confounding variable.
\end{abstract}

\section{INTRODUCTION}

Long Island Sound, a large estuary in New York, USA, is characterized by strong seasonal variations in temperature and stratification of the water column. Surface temperatures range from ca $-1.0^{\circ} \mathrm{C}$ (in January) to $22^{\circ} \mathrm{C}$ (in August), and the $40 \mathrm{~m}$ water column is well mixed from September through April. Associated with seasonal variations in water-column stratification are changes in the vertical distribution of phytoplankton biomass, cell size and taxonomic composition. When the water column is stratified, most of the chlorophyll is concentrated in the $<20 \mu \mathrm{m}$ size fraction, and often all of it is in the $<10 \mu \mathrm{m}$ fraction (Peterson 1986, Bellantoni \& Peterson 1987, Peterson \&

- Address and affiliation after January 1, 1991: Department of Marine Sciences, University of Connecticut, Groton, Connecticut 06340, USA

- Current address: NOAA, Center for Ocean Analysis and Prediction, 2560 Garden Road, Suite 101, Monterey, California 93940, USA
Bellantoni 1987). During stratification monads and heterotrophic nanoflagellates dominate the phytoplankton and dinoflagellates are conspicuous, whereas diatoms dominate when the water column is mixed (Conover 1956, Capriulo \& Carpenter 1983). Variations in phytoplankton abundance are also somewhat cyclic, with spring and autumn blooms occurring each year in February-March and September, respectively. Lesser blooms occur aperiodically, driven by storms.

For Temora longicornis, an omnivorous copepod which dominates the zooplankton biomass in Long Island Sound from December through July, all of the environmental signals discussed above may affect feeding rates. Seasonal increases in temperature should lead to increased feeding rates, although the total amount of food consumed may not increase greatly during spring/summer because decreases in body size associated with development at warmer temperatures could offset increased feeding rates. Thus temperature may not affect greatly the total amount of food ingested daily on a per individual basis.

The ingestion rate of this copepod in experimental 
enclosures is dependent on phytoplankton concentration and size (e.g. O'Connors et al. 1980, Dam 1986). Therefore, one would expect the in situ feeding behavior of this copepod to reflect the changes in food abundance and size described above. This expectation is supported by recent work which shows a link between seasonal changes in chlorophyll concentration and the fecundity of this species (Peterson 1985, Peterson $\&$ Bellantoni 1987). These studies have also shown that both the total and the $<10 \mu \mathrm{m}$ size fraction chlorophyll concentration are poor indices of egg production, suggesting that this species cannot efficiently utilize small algae and must rely on larger phytoplankton for maximum rates of egg production. Furthermore, the volume swept clear of many copepod species increases with increasing cell size (e.g. Frost 1972, Nival \& Nival 1976, Bartram 1980, Berggreen et al. 1988). Recent cinematographic studies indicate that cells $>10 \mu \mathrm{m}$ are individually handled and have higher probabilities of being encountered than their size and abundance alone might predict (Price et al. 1983, Price \& Paffenhöfer 1985).

The general objectives of this study were (1) to examine the possible linkages between seasonal changes in abundance and size of phytoplankton and the in situ herbivorous feeding behavior of female Temora longicornis, and (2) to determine how such relationships might be modified by changes in body size. We tested the hypothesis that temporal changes in the in situ herbivorous feeding behavior of $T$. longicornis should be better correlated with changes in concentration of the larger phytoplankton than with changes in total algal (= chlorophyll) concentration.

The hypothesis was tested by monitoring chlorophyll concentration in different size fractions (total, $>10 \mu \mathrm{m}$ and $>20 \mu \mathrm{m}$ ) and correlating these concentrations with gut pigment content (GPC) and ingestion rates (IR) of female Temora longicornis. We chose chlorophyll size fraction as an index of algal availability because of its simplicity and convenience (Runge \& Ohman 1982) and because another index of food quantity and quality (protein concentration) is well correlated with chlorophyll concentration (W. Peterson unpubl. data). We also chose to test the hypothesis by using specimens and chlorophyll concentration from one depth $-20 \mathrm{~m}$. This depth was selected because it includes the daytime depth of females at all times during their period of occurrence in the Sound (Peterson 1985). Females are always found at this depth regardless of the presence of a thermocline, whereas they tend to avoid the upper mixed layer after stratification in early May, and disappear altogether from the upper $10 \mathrm{~m}$ by July (Dam 1989). Furthermore, we tested the hypothesis by using only daytime values (a detailed description of the diel feeding behavior of $T$. longicornis throughout its entire growth season is given in Dam 1989). The conditions in this study will not yield a complete view of the feeding ecology of this species; however, they provide an internally consistent data set appropriate for the objectives of this research.

\section{MATERIALS AND METHODS}

Cruises were conducted at about weekly intervals between February and August from 1985 to 1987, in the central basin of Long Island Sound, New York, USA, at a station in $37 \mathrm{~m}$ of water (for station location see Peterson 1985) from 10:00 to 14:00 h. During each cruise, samples for measurements of chlorophyll a (chl a) concentration (total $<10 \mu \mathrm{m}$ and $<20 \mu \mathrm{m}$ ) and temperature were collected at $20 \mathrm{~m}$ as described by Peterson (1985). A pooled sample of near-surface water $(1+3+5 \mathrm{~m})$ was also collected for chlorophyll measurement in the different size fractions. The percentage of chlorophyll concentration in the $<10 \mu \mathrm{m}$ and $<20 \mu \mathrm{m}$ size fractions near the surface $(1+3+5 \mathrm{~m})$ and at $20 \mathrm{~m}$ usually differed by less than $20 \%$. This suggests that phytoplankton size fractions from this depth were representative for the water column.

A horizontal tow was taken at $20 \mathrm{~m}$ during each cruise with a $0.57 \mathrm{~m}$ diameter, $202 \mu \mathrm{m}$ mesh net and the catch preserved in $5 \%$ formalin solution. In the laboratory, prosome lengths of 30 preserved female Temora longicornis were measured and converted to dry weights from a regression of dry weight vs prosome length (Dam 1989). The equation used was: dry wt = $27.05 \times$ (prosome length) ${ }^{2.62}$, where prosome length is in $\mathrm{mm}_{\text {; }}$ weight is in $\mu \mathrm{g} ; \mathrm{n}=9, \mathrm{r}^{2}=0.94, \mathrm{p}<0.01$.

Specimens for measurements of GPC were collected from $20 \mathrm{~m}$. The net was bridleless, with a line of rope attached to one side of the net ring and a $5 \mathrm{~kg}$ weight to the opposite side. When lowered and retrieved the net mouth remained vertical and thus did not sample. While at $20 \mathrm{~m}$ the net sampled for 2 to $5 \mathrm{~min}$ while the boat drifted. In 1985 and until May of 1986 a portion of the catch from the tow was passed through a $500 \mu \mathrm{m}$ Nitex screen and gently rinsed with filtered (GF/C) seawater to remove debris and phytoplankton that may have adhered to the copepods. Then, duplicate samples of 10 female Temora longicornis were picked with the aid of a dissecting scope and placed in plastic centrifuge tubes containing a few milliliters of $90 \%$ acetone. This operation took ca $5 \mathrm{~min}$. The tubes were immediately placed in a cooler filled with crushed ice until return to the laboratory. Starting in June 1986 , specimens were screened and rinsed, then transferred onto $4.5 \mathrm{~cm}$ glass fiber filters (GF/A) under low vacuum. The filters were placed in a plastic petri dish, covered with aluminum foil, and kept in crushed ice in 
Table 1. Summary of statistical comparisons of gut pigment content (ng pigment female ${ }^{-1}$ ) for female Temora longicornis frozen before being analyzed and not frozen. The mear ( $\overline{\mathrm{X}}$ ), standard deviation (SD) and number of samples (n) for each case are shown. Each sample is the mean of 10 pooled copepods. The null hypothesis (no difference between means) was tested by $t$-tests. $t_{\mathrm{s}}$ is the test statistic when sample variances are equal. $t^{\prime}$ is the test statistic when sample variances are unequal (Sokal \& Rohlf 1981). Numbers in parentheses indicate the number of hours the sample was frozen before being analyzed. F: field-collected copepods; L: copepods from laboratory; ns: not significantly different; " $p<0.01$

\begin{tabular}{|c|c|c|c|c|c|c|c|c|}
\hline \multirow[t]{2}{*}{ Expt (h) } & \multicolumn{3}{|c|}{ Frozen } & \multicolumn{3}{|c|}{ Not frozen } & \multirow[t]{2}{*}{$t_{s}$} & \multirow[t]{2}{*}{$t^{\prime}{ }_{s}$} \\
\hline & $\bar{x}$ & $\mathrm{SD}$ & $\mathrm{n}$ & $\overline{\mathrm{X}}$ & $\mathrm{SD}$ & $\mathrm{n}$ & & \\
\hline $1 \mathrm{~F}$ & 0.390 & 0.290 & 3 & 0.250 & 0.079 & 4 & & $0.81 \mathrm{~ns}$ \\
\hline $2 F(264)$ & 0.265 & 0.110 & 4 & 0.225 & 0.130 & 4 & $0.47 \mathrm{~ns}$ & \\
\hline $3 \mathrm{~F}(264)$ & 0.225 & 0.099 & 4 & 0.140 & 0.012 & 4 & & $1.70 \mathrm{~ns}$ \\
\hline $4 \mathrm{~F}(264)$ & 0.562 & 0.062 & 4 & 0.850 & 0.136 & 4 & $2.41 \mathrm{~ns}$ & \\
\hline $4 \mathrm{~F}(264)$ & 2.670 & 0.896 & 4 & 1.530 & 0.306 & 4 & $3.85^{\circ}$ & \\
\hline $6 \mathrm{~L} \quad(48)$ & 2.200 & 0.250 & 4 & 2.330 & 0.870 & 4 & & $0.81 \mathrm{~ns}$ \\
\hline $7 \mathrm{~F}(240)$ & 0.280 & 0.073 & 4 & 0.280 & 0.100 & 4 & $0.00 \mathrm{~ns}$ & \\
\hline
\end{tabular}

a cooler until return to the laboratory. Samples were processed upon arriving in the laboratory $(1$ to $3 \mathrm{~h}$ after the samples were taken) or stored in a freezer and processed within $1 \mathrm{wk}$. Frozen samples were allowed to thaw for $5 \mathrm{~min}$, and copepods were individually picked in dim light. Triplicate or quadruplicate samples of 10 female $T$. longicomis were usually taken for fluorometric analysis. Details of the fluorometric analysis and equations for calculating pigment content are given in Dam \& Peterson (1988).

Nicolajsen et al. (1983) found that freezing of samples resulted in a $30 \%$ loss of GPC compared to freshly picked copepods. To investigate this possibility, on 7 different occasions the GPC of a group of freshly picked females and a group frozen in GF/A filters and stored from $3 \mathrm{~h}$ to $11 \mathrm{~d}$ was compared. The conclusion from these experiments was that freezing of specimens did not result in a decrease in GPC (Table 1).

Algal ingestion rates were estimated from the product of GPC and gut clearance rate constants. The latter were estimated using a linear equation relating gut clearance rate constant and temperature, derived for female Temora longicornis (Dam \& Peterson 1988). The temperature at $20 \mathrm{~m}$ was used in calculations of gut clearance rate constants.

The functional response of GPC, IR, and their weight-specific equivalent to chlorophyll concentration in the different size fractions was examined using the modified (Parsons et al. 1967) Ivlev equation:

$$
Y=Y_{\max }\left[1-\mathrm{e}^{-\alpha\left(X-X_{0}\right)}\right]
$$

where $Y=G P C$, IR, or their weight-specific equivalent (GPC or IR $\mu \mathrm{g}^{-1} \mathrm{dry} w \mathrm{t}$ ); $Y_{\max }=$ maximum GPC or IR; $\alpha=$ rate at which $Y$ approaches $Y_{\max } X=$ chlorophyll concentration in the different size fractions; and $X_{0}=$ threshold concentration below which GPC or IR would be zero. Details of model fitting are given in Dam (1989).

\section{RESULTS}

\section{Seasonal variability in body size, GPC and IR}

Body size of female Temora longicornis was fairly constant from February through April, between 1.1 and $1.2 \mathrm{~mm}$. This spanned a temperature range of ca 1 to $8^{\circ} \mathrm{C}$. Fig. 1 shows that prosome lengths began to decrease in April from 1.1-1.2 $\mathrm{mm}$ to $0.9 \mathrm{~mm}$ in June. In 1986, when females occurred in the Sound through August, individuals as small as $0.7 \mathrm{~mm}$ were found. This pattern is similar to that reported previously by Deevey (1960). Dry weight declined by a factor of 4 during the season, from ca $40 \mu \mathrm{g}$ in March to $10 \mu \mathrm{g}$ in June and July.

Changes in GPC and IR on a per individual basis tracked changes in chlorophyll concentration thoughout the season (Fig. 2). Maximum GPC and IR occurred during the spring bloom when a large proportion of the chlorophyll was in the $>20 \mu \mathrm{m}$ size fraction, and minima occurred in late spring and early summer when chlorophyll concentrations were relatively low. During 1986 a second peak in GPC and IR was apparent from late June through early July. This coincided with a bloom of the diatom Thalassiosira rotula (J. Chang unpubl. data). This period was also characterized by the highest primary productivity rates (Dam 1989) and the highest egg-production rates by Temora longicornis for the entire season (W. Peterson unpubl. data).

Some of the seasonal variability in GPC and IR was due to changes in water temperature. For example, the ratio of maximum to minimum GPC was ca 18, but only 7.5 for IR. Seasonal increase in temperature resulted in faster gut passage times $\left(\mathrm{Q}_{10}=2.2\right.$; see Dam \& Peterson 1988), and hence a relative increase in IR as the water column warmed.

Agreement of weight-specific GPC and IR with changes in chlorophyll concentration was not as good 

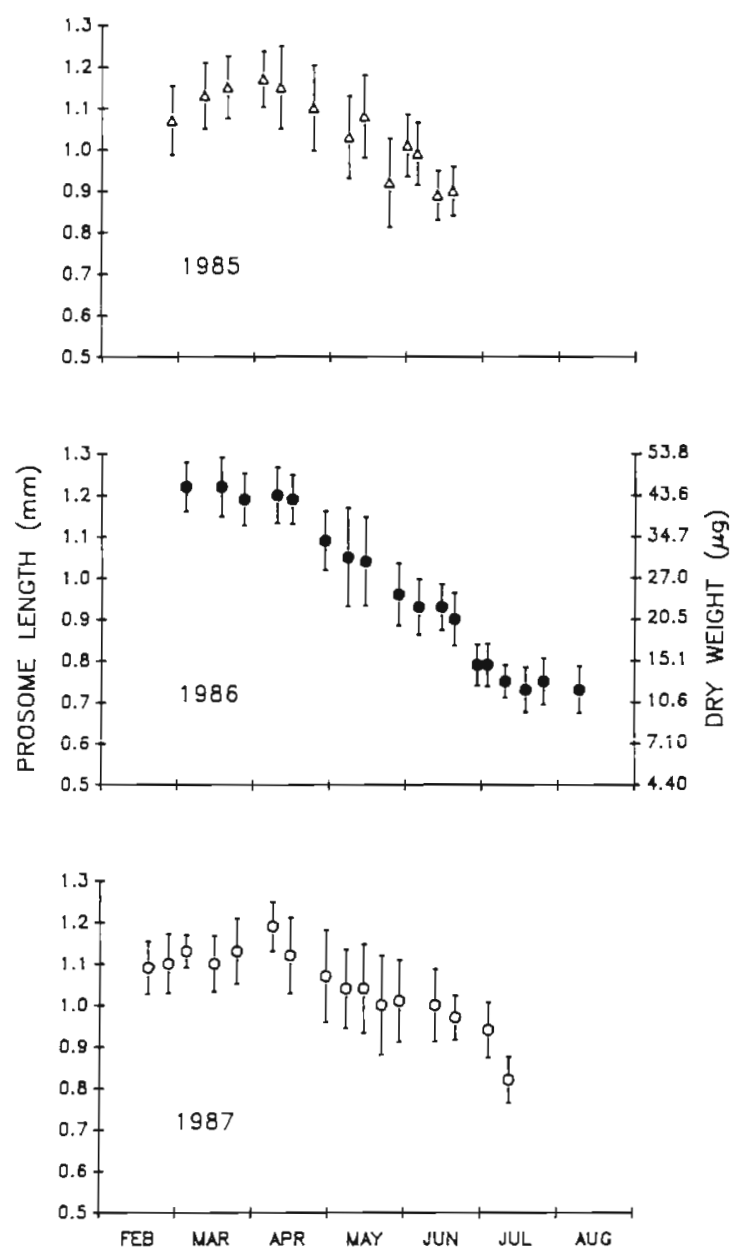

Fig. 1. Temora longicornis. Seasonal changes in mean prosome length of female copepods collected at the sampling station in Long Island Sound. Vertical bars represent standard deviation. Weight scale is the same for all 3 graphs

(Fig. 2). With the exception of the 2 wk period from late June to early July 1986, the ratio of maximum to minimum weight-specific GPC and IR was ca 10 and 3.5 respectively, about one-half of the same ratios calculated on a per individual basis.

\section{Functional response of GPC and IR to changes in chlorophyll concentration}

Functional responses of GPC and IR and their weight-specific equivalents are shown in Figs. $3 \& 4$. The data for the $2 \mathrm{wk}$ period from late June to early July 1986 were excluded from the regressions because analysis of residuals (Sokal \& Rohlf 1981) indicated that they affected the slopes unduly. Exclusion of these data only resulted in a reduction of sample size of $5 \%$ (from 132 to 125 values). These data represent a period when clearly factors other than size and concentration of phytoplankton strongly affected ingestion rates of these copepods.

The shape of the functional response of Temora longicornis depended on the size of phytoplankton considered. There was little evidence of saturation of GPC or IR with increasing algal concentration for total and $>10$ um chlorophyll, particularly for the former (Fig. 3); i.e., for the case of total chlorophyll the amount of variance explained by the linear fit was the same as that explained by the curvilinear fit (Tables $2 \& 3$ ). However, saturation in GPC was apparent when the $>20 \mu \mathrm{m}$ phytoplankton was considered as the food source. Saturation of IR was apparent when either the $>10 \mu \mathrm{m}$ or the $>20 \mu \mathrm{m}$ phytoplankton was considered as the food source (Fig. 4).

The amount of variance in GPC and IR explained by the regressions also increased as the size of phytoplankton increased. This is in agreement with the hypothesis that net phytoplankton is a better index of algal availability for Temora longicornis than is total phytoplankton. However, the amount of variance explained by the regressions of weight-specific GPC and IR vs chlorophyll was lower in all cases considered. One possibility is that GPC and IR throughout the season were more sensitive to other variables such as body size or temperature than to algal concentration. This hypothesis was tested employing a multivariate regression analysis. The basic model used was:

$$
\begin{aligned}
& \log (Y+1)=A+B \log (S+1)+C \log (T+1)+ \\
& D \log (W+1)+E \log \left(S^{2}+1\right)+E \log [(S T)+1]+ \\
& F \log [(S W)+1]+G \log [(T W)+1]
\end{aligned}
$$

where $Y$ is the dependent variable (e.g. GPC); $S$ is algal concentration; $T$ is temperature; $W$ is female dry weight, and $A$ to $G$ are fitted constants. The log (variable +1$)$ transformation was used to linearize the relationship and to avoid taking the log of zero. This was necessary for phytoplankton in the $>10 \mu \mathrm{m}$ and $>20 \mu \mathrm{m}$ size fraction. The quadratic term for algal concentration was introduced to allow for possible nonlinearity of ingestion rate not achieved by the logarithmic transformation. The product of variables was introduced to allow for interaction between them. When IR was the dependent variable, temperature was not included in the regression because IR and temperature are not independent in this study. We employed a forward regression procedure (Sokal \& Rohlf 1981) for the analysis - chlorophyll concentration was regressed against the dependent variable first; then, the other variables were added one at a time and the coefficient of determination of each multiple regression was compared with that of the previous one. Only variables that increased significantly the amount of variance explained were kept in the models.

Two main results were apparent from the multivari- 

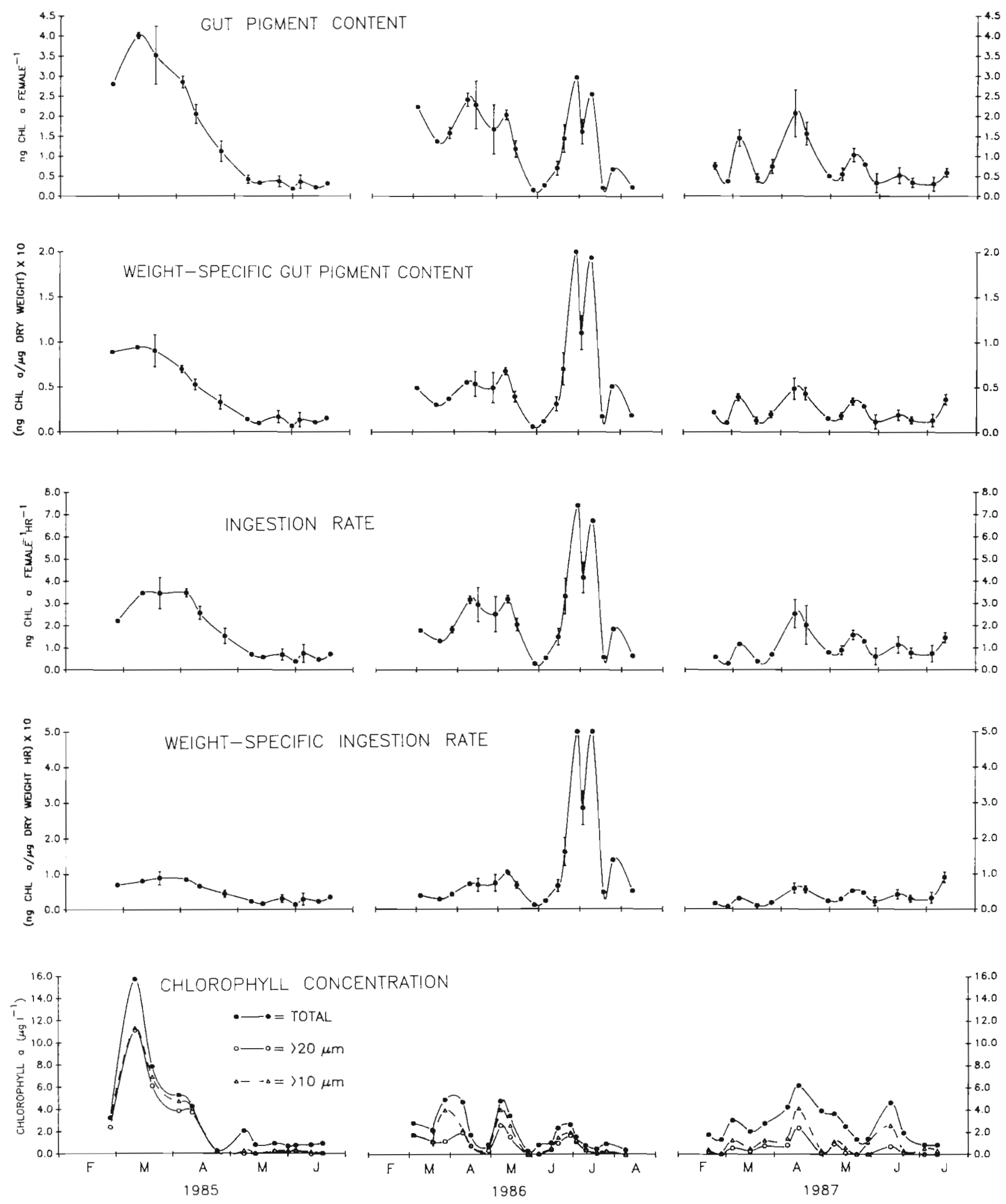

Fig. 2. Temora longicornis. Seasonal variability in gut pigment content, weight-specific gut pigment content, ingestion rate, and weight-specific ingestion rate and chlorophyll a concentration in different size fractions in Long Island Sound from 1985 to 1987. Means and ranges of duplicates of the above variables are shown from 1985 to May of 1986. Means and standard deviations of triple or quadruple replicates are shown from May 1986 on. Some bars are smaller than the points. Chlorophyll values represent single observations 


\section{GUT PIGMENT CONTENT}
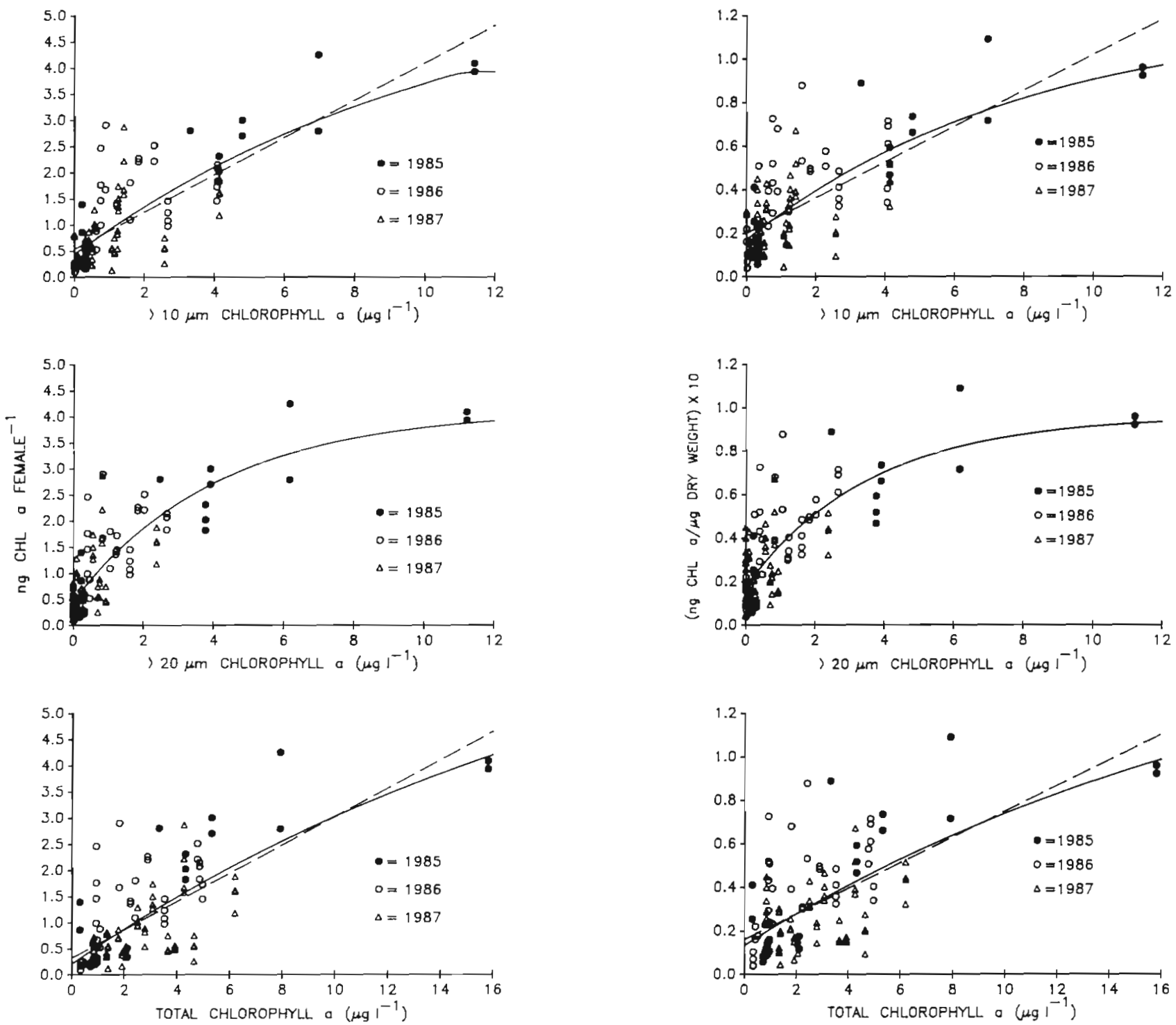

Fig. 3. Temora longicomis. Functional response of gut pigment content (left) and weight-specific gut pigment content (right) to $>10 \mu \mathrm{m},>20 \mu \mathrm{m}$ and total chlorophyll a concentration. Curves (solid line) represent least-square nonlinear fits using the Ivlev model (Eq. 1). Dashed lines represent the least-square linear fits and are shown only when they fit the data as well as $(<2 \%$ difference) the nonlinear model (see Tables $2 \& 3$ ). Observations from 3 cruises (last week of June and first 2 weeks of July 1986) were excluded from the analysis (see text)

ate analyses (Table 4). First, when GPC was the dependent variable, the coefficient of determination remained either unchanged or increased slightly (up to $17 \%$ ) when variables other than algal concentration were incorporated in the regression. Second, the standard partial regression coefficients for algal concentration were always greater than those of the other variables. These coefficients are directly comparable because they are expressed in standard form. A similar exercise for the case of IR (not shown here, but pre- sented in Dam 1989) revealed that addition of body size as an independent variable was not significant. These results indicate that GPC and IR of Temora longicornis throughout the season were more sensitive to algal concentration than to body size (or temperature in the case of GPC).

Another interesting result from the multivariate analyses was the negative effect of temperature on GPC. This effect may be real or may reflect negative covariability between temperature and chlorophyll (Table 4). 


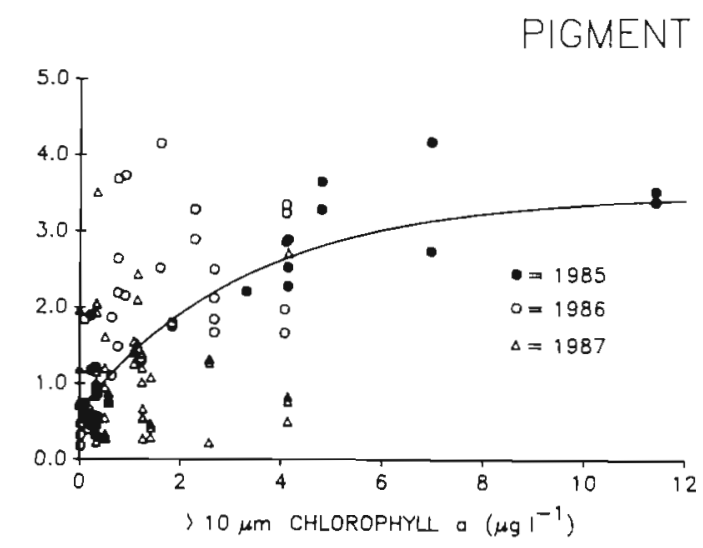

\section{INGESTION RATE}
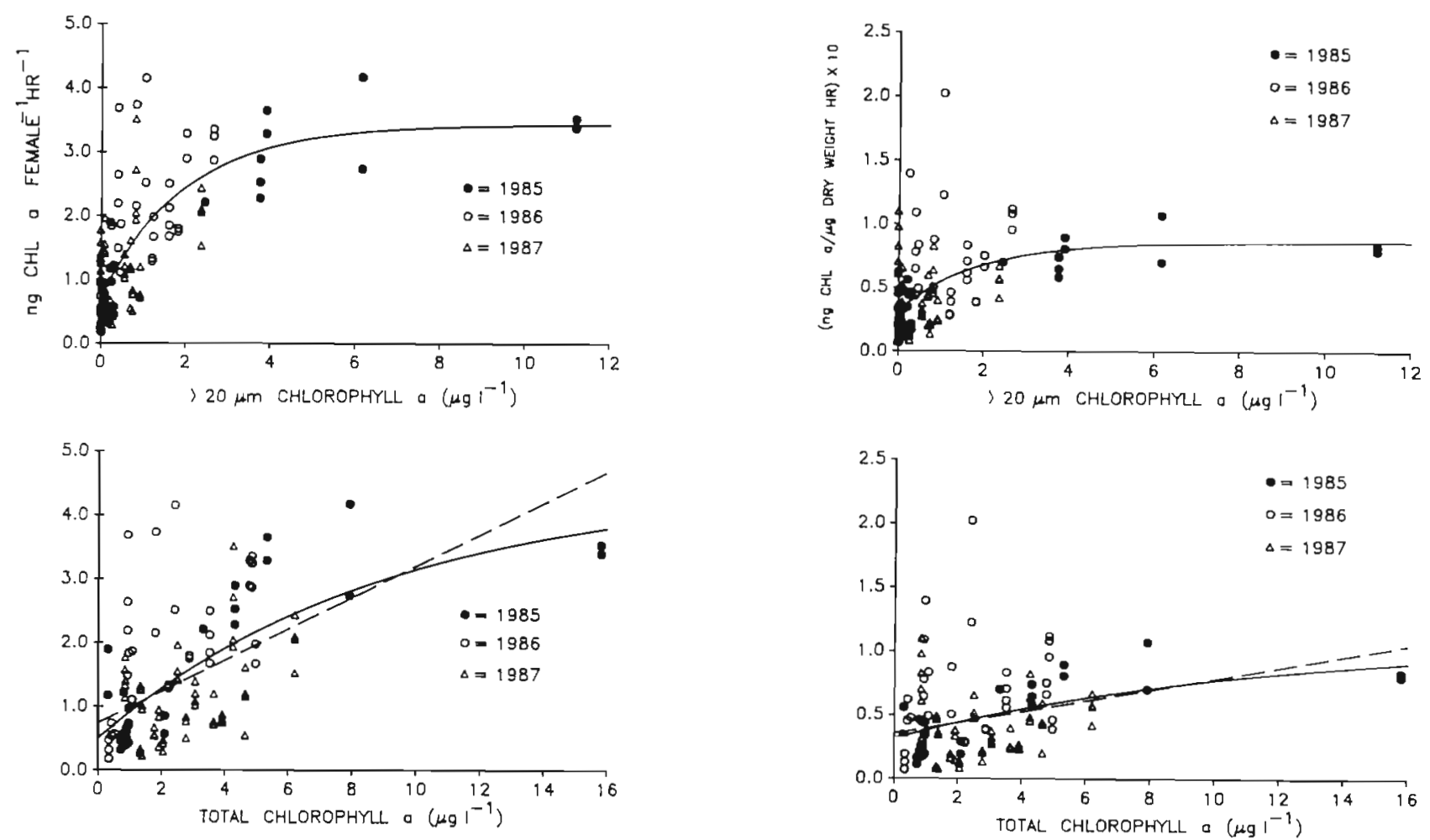

Fig. 4. Temora longicornis. Functional response of ingestion rate (left) and weight-specific ingestion rate to $>10 \mu \mathrm{m},>20 \mu \mathrm{m}$ and total chlorophyll a concentration. Curves and dashed lines as in Fig. 3. Observations from 3 cruises (last week of June and first 2 weeks of July 1986) were excluded from the analysis (see text)

\section{DISCUSSION}

Previous studies on feeding behavior of Temora longicornis have shown the existence of diel cycles, with gut content generally maximum at night (Baars \& Oosterhuis 1984, Head et al. 1984, Kiørboe et al. 1985, Dam 1986, Tiselius 1988). Differences in gut content with depth have also been reported (Baars \& Oosterhuis 1984, Head et al. 1984, Dam 1989). Our study was not designed to study either diel or spatial (depth-related) changes in feeding behavior. Instead, our purpose was to investigate effects of seasonal changes in algal con- centration and size and copepod body size on hourly ingestion rates. Thus, we confined our study to 1 period of the day $(10: 00$ to $14: 00 \mathrm{~h})$ and to 1 depth $(20 \mathrm{~m})$.

The results from this study indicate that in general seasonal changes in the in situ feeding behaviour of Temora longicornis can be predicted from changes in chlorophyll concentration. The degree of prediction and inferences about the feeding ecology of this species, however, vary depending on how phytoplankton availability is defined.

In the case of Temora longicornis, total chlorophyll concentration is a poor index of phytoplankton availa- 
Table 2. Temora longicornis. Summary of statistical analyses from nonlinear regressions of gut content, weight-specific gut content, and weight-specific ingestion rate vs total, $>10 \mu \mathrm{m}$ and $>20 \mu \mathrm{m}$ chlorophyll a concentration $\left(\mu \mathrm{g} \mathrm{l}^{-1}\right)$. The parameters are those from Eq. (1). $\mathrm{r}^{2}=$ coefficient of determination. $C_{s}$ is the saturation concentration $\left(\mu \mathrm{g} \mathrm{l}^{-1}\right.$ ) defined to be the concentration at which $Y$ was within $95 \%$ of $Y_{\max }$. All analyses are based on $\mathrm{n}=125$

\begin{tabular}{|c|c|c|c|c|c|c|}
\hline Variable & $\mathrm{Chl} \mathrm{a}$ & $Y_{\max } \pm(95 \% \mathrm{CI})$ & $\alpha \pm(95 \% \mathrm{CI})$ & $X_{0} \pm(95 \% \mathrm{Cl})$ & $r^{2}$ & $C_{\mathrm{s}}$ \\
\hline $\begin{array}{l}\text { Gut content } \\
\left.\text { (ng chI a female }{ }^{-1}\right)\end{array}$ & $\begin{array}{l}\text { Total } \\
>10 \mu \mathrm{m} \\
>20 \mu \mathrm{m}\end{array}$ & $\begin{array}{l}8.006(7.961) \\
5.910(2.479) \\
4.126(0.725)\end{array}$ & $\begin{array}{l}0.045(0.057) \\
0.091(0.053) \\
0.241(0.069)\end{array}$ & $\begin{array}{l}-0.588(0.768) \\
-0.835(0.359) \\
-0.493(0.121)\end{array}$ & $\begin{array}{l}0.52 \\
0.61 \\
0.71\end{array}$ & $\begin{array}{l}8.7 \\
6.7\end{array}$ \\
\hline $\begin{array}{l}\text { Weight-specific gut content } \\
{\left[\left(\mathrm{ng} \text { chl } a \mu g^{-1} \text { dry wt }\right) \times 10\right]}\end{array}$ & $\begin{array}{l}\text { Total } \\
>10 \mu \mathrm{m} \\
>20 \mu \mathrm{m}\end{array}$ & $\begin{array}{l}1.751(2.622) \\
1.211(0.813) \\
0.965(0.272)\end{array}$ & $\begin{array}{l}0.047(0.098) \\
0.122(0.155) \\
0.277(0.143)\end{array}$ & $\begin{array}{l}-1.688(1.785) \\
-1.238(1.009) \\
-0.738(0.290)\end{array}$ & $\begin{array}{l}0.39 \\
0.53 \\
0.61\end{array}$ & $\begin{array}{l}2.0 \\
3.8\end{array}$ \\
\hline $\begin{array}{l}\text { Ingestion rate } \\
\text { (ng chl a female }{ }^{-1} \mathrm{~h}^{-1} \text { ) }\end{array}$ & $\begin{array}{l}\text { Total } \\
>10 \mu \mathrm{m} \\
>20 \mu \mathrm{m}\end{array}$ & $\begin{array}{l}4.492(2.885) \\
3.503(1.186) \\
3.440(0.505)\end{array}$ & $\begin{array}{l}0.109(0.110) \\
0.295(0.237) \\
0.496(0.186)\end{array}$ & $\begin{array}{l}-1.090(1.029) \\
-0.692(0.525) \\
-0.483(0.186)\end{array}$ & $\begin{array}{l}0.36 \\
0.49 \\
0.57\end{array}$ & $\begin{array}{l}2.8 \\
3.4\end{array}$ \\
\hline $\begin{array}{l}\text { Weight-specific ingestion rate } \\
{\left[\left(\text { ng chl } a \mu g^{-1} \text { dry wt } h^{-1}\right) \times 10\right]}\end{array}$ & $\begin{array}{l}\text { Total } \\
>10 \mu \mathrm{m} \\
>20 \mu \mathrm{m}\end{array}$ & $\begin{array}{l}1.087(1.736) \\
0.872(0.400) \\
0.867(0.194)\end{array}$ & $\begin{array}{l}0.090(0.286) \\
0.330(0.648) \\
0.538(0.451)\end{array}$ & $\begin{array}{l}-3.861(6.669) \\
-1.285(2.981) \\
-0.866(0.753)\end{array}$ & $\begin{array}{l}0.09 \\
0.20 \\
0.23\end{array}$ & $\begin{array}{l}1.1 \\
1.9\end{array}$ \\
\hline
\end{tabular}

Table 3. Temora longicornis. Summary of statistical analyses from linear regressions of gut content, weight-specific gut content, ingestion rate and weight-specific ingestion rate vs total, $>10 \mu \mathrm{m}$ and $>20 \mu \mathrm{m}$ chlorophyll a concentration $\left(\mu \mathrm{I} \mathrm{l}^{-1}\right)$. $A$ and $B$ are the intercept and slope of the regression, respectively. $\mathrm{r}^{2}=$ coefficient of determination. All analyses are based on $\mathrm{n}=125$

\begin{tabular}{|c|c|c|c|c|}
\hline Variable & Chl a & $A \pm(95 \% C l)$ & $B \pm(95 \% \mathrm{Cl})$ & $r^{2}$ \\
\hline $\begin{array}{l}\text { Gut content } \\
\text { (ng chl a female }{ }^{-1} \text { ) }\end{array}$ & $\begin{array}{l}\text { Total } \\
>10 \mu \mathrm{m} \\
>20 \mu \mathrm{m}\end{array}$ & $\begin{array}{l}0.326(0.165) \\
0.531(0.125) \\
0.644(0.112)\end{array}$ & $\begin{array}{l}0.271(0.045) \\
0.357(0.051) \\
0.406(0.054)\end{array}$ & $\begin{array}{l}0.52 \\
0.60 \\
0.62\end{array}$ \\
\hline $\begin{array}{l}\text { Weight-specific gut content } \\
{\left[\left(\text { ng chl } a \mu g^{-1} \mathrm{~d} r y \text { wt }\right) \times 10\right]}\end{array}$ & $\begin{array}{l}\text { Total } \\
>10 \mu \mathrm{m} \\
>20 \mu \mathrm{m}\end{array}$ & $\begin{array}{l}0.161(0.045) \\
0.199(0.035) \\
0.230(0.031)\end{array}$ & $\begin{array}{l}0.059(0.012) \\
0.082(0.014) \\
0.092(0.016)\end{array}$ & $\begin{array}{l}0.40 \\
0.52 \\
0.52\end{array}$ \\
\hline $\begin{array}{l}\text { Ingestion rate } \\
\text { (ng chl a female }{ }^{-1} \mathrm{~h}^{-1} \text { ) }\end{array}$ & $\begin{array}{l}\text { Total } \\
>10 \mu \mathrm{m} \\
>20 \mu \mathrm{m}\end{array}$ & $\begin{array}{l}0.744(0.239) \\
0.933(0.170) \\
1.075(0.159)\end{array}$ & $\begin{array}{l}0.246(0.061) \\
0.342(0.069) \\
0.371(0.078)\end{array}$ & $\begin{array}{l}0.34 \\
0.43 \\
0.41\end{array}$ \\
\hline $\begin{array}{l}\text { Weight-specific ingestion rate } \\
{\left[\left(\text { ng chl } a \mu g^{-1} \text { dry wt } h^{-1}\right) \times 10\right]}\end{array}$ & $\begin{array}{l}\text { Total } \\
>10 \mu \mathrm{m} \\
>20 \mu \mathrm{m}\end{array}$ & $\begin{array}{l}0.357(0.080) \\
0.368(0.064) \\
0.399(0.059)\end{array}$ & $\begin{array}{l}0.043(0.021) \\
0.070(0.025) \\
0.074(0.029)\end{array}$ & $\begin{array}{l}0.10 \\
0.18 \\
0.16\end{array}$ \\
\hline
\end{tabular}

bility. This is supported by 2 lines of evidence. First, the amount of variance of GPC and IR explained by changes in total phytoplankton concentration was lower than that explained by changes in the $>10 \mu \mathrm{m}$ and $>20 \mu \mathrm{m}$ phytoplankton concentration (Table 2). Using this criterion, the $>20 \mu \mathrm{m}$ phytoplankton was the most suitable indicator of phytoplankton available to $T$. longicornis. Second, there was no indication of saturation of IR when total phytoplankton was considered as food, in contrast to when phytoplankton in the $>10 \mu \mathrm{m}$ and $>20 \mu \mathrm{m}$ size fractions was considered as food (Fig. 4). Saturation of IR was also observed by $O^{\prime}$ Connors et al. (1980), who studied the feeding behavior of $T$. longicornis fed natural particle assemblages. It may be argued that a saturation response in our case was observed because, for a given chlorophyll concentration, most of the data represent minimum (daytime) values of GPC and IR. This would only be the case if daytime values were indeed significantly lower than nighttime values. This is unlikely to be the case in this study - Dam (1989) was unable to show that nighttime GPC in female $T$. longicornis from $20 \mathrm{~m}$ was significantly greater at night than during the day on 7 different diel cruises. Moreover, in 3 of these cruises, in which both gut content and chlorophyll concentration were monitored throughout the day, diel changes in gut content were related to changes in chlorophyl concentration.

Conclusions about the degree to which ingestion rate of Temora longicornis is food-limited under natural conditions will depend on which size fraction is considered as food. When total phytoplankton was considered as available food, T. longicornis appeared foodlimited during its entire growth season, a conclusion 
Table 4. Temora longicornis. Multivariate regression analysis. $G=$ Gut pigment content; $S=$ chlorophyll concentration; $T=$ temperature; $W=$ female dry weight. All regressions based on $n=125$. Coefficients in the multivariate regressions are shown in standard form so that they can be directly compared. $F_{\mathrm{s}}=F$-statistic for the multivariate regression (all $F_{\mathrm{s}}$ were significant; $p<0.001) . r^{2}=$ coefficient of determination. Addition of variable significant at: ${ }^{p}<<0.005 ;{ }^{\cdots} p<0.001$. Only significant variables are shown in the equations

\begin{tabular}{|c|c|c|}
\hline Equation & $F_{\mathrm{s}}$ & $\mathrm{r}^{2}$ \\
\hline \multicolumn{3}{|l|}{ Total chlorophyll } \\
\hline $\log (G+1)=0.023+0.509 \log (S+1)$ & 117.73 & 0.489 \\
\hline $\log (G+1)=0.146+0.619 \log (S+1)-0.203 \log (T+1)$ & 67.07 & $0.524^{\circ}$ \\
\hline $\log (G+1)=-0.524+0.497 \log (S+1)-0.027 \log (T+1)+0.309 \log (W+1)$ & 50.57 & $0.556^{\bullet}$ \\
\hline $\log (G+1)=-1.091+1.598 \log (S+1)+1.238 \log (T+1)+0.471 \log (W+1)-1.307 \log [(S T)+1]$ & 43.23 & $0.590^{\circ}$ \\
\hline \multicolumn{3}{|l|}{$>20 \mu \mathrm{m}$ chlorophyll } \\
\hline $\log (G+1)=0.156+0.580 \log (S+1)$ & 259.85 & 0.679 \\
\hline $\log (G+1)=0.247+0.770 \log (S+1)-0.177 \log (T+1)$ & 146.49 & $0.706^{*}$ \\
\hline $\log (G+1)=-0.329+0.679 \log (S+1)-0.023 \log (T+1)+0.252 \log (W+1)$ & 109.20 & $0.730^{\circ}$ \\
\hline \multicolumn{3}{|l|}{$>10 \mu \mathrm{m}$ chlorophyll } \\
\hline $\log (G+1)=0.121+0.512 \log (S+1)$ & 180.33 & 0.594 \\
\hline $\log (G+1)=0.248+0.700 \log (S+1)-0.242 \log (T+1)$ & 112.22 & $0.648^{\cdots}$ \\
\hline $\log (G+1)=-0.327+0.613 \log (S+1)-0.083 \log (T+1)+0.253 \log (W+1)$ & 82.39 & $0.671^{\circ}$ \\
\hline $\log (G+1)=-0.509+1.508 \log (S+1)+0.151 \log (W+1)+0.307 \log (W+1)-0.367 \log [(S T)+1]$ & 66.05 & $0.688^{\circ}$ \\
\hline
\end{tabular}

also reached by Poulet (1978) and Mayzaud \& Poulet (1978), who correlated seasonal changes in ingestion rates with total particle concentration. However, when the $>10 \mu \mathrm{m}$ or $>20 \mu \mathrm{m}$ phytoplankton was considered as food, it was apparent that IR was not foodlimited all the time. The extent to which IR of $T$. longicornis in Long Island Sound is food-limited will depend on the food-size spectrum that it will encounter throughout the season; for example, food-limitation will be less severe before the onset of thermal stratificatioin of the water column, when algal size tends to be large. Food-limitation will be severe following the onset of seasonal stratification of the water column, because net phytoplankton abundance is low.

Estimated $I_{\max }$ (maximum IR) of Temora longicornis from this study was $3.5 \pm 1.2 \mathrm{ng}$ chl a female ${ }^{-1} \mathrm{~h}^{-1}$ (= $84 \pm 28.8 \mathrm{~d}^{-1}$ ) reached at a chlorophyll concentration of $3 \mu \mathrm{g} 1^{-1}$ (Table 2). The value of $I_{\max }$ is in general agreement with the results of the study by Dam (1986) in which IR was estimated in the laboratory by monitoring increase of GPC with time (up to $1 \mathrm{~h}$ ). $\mathrm{O}^{\circ}$ Connors et al. (1980) reported $I_{\max }$ of $50.6 \pm 18.7 \times 10^{6} \mu \mathrm{m}^{3} \mathrm{~d}^{-1}$ and a critical concentration of $1.9 \pm 0.7 \times 10^{6} \mu^{3}$ $\mathrm{ml}^{-1}$. Assuming a $\mathrm{C}$ :chl ratio of 50 (Malone \& Chervin 1979, Dagg \& Turner 1982, Durbin et al. 1983), and a cell volume to cell carbon conversion factor of $0.11 \mu \mathrm{g} \mathrm{C}$ per $10^{6} \mu \mathrm{m}^{3}$ (Strathmann 1967), these values are equivalent to $111.3 \pm 41.1 \mathrm{ng} \mathrm{chl} \mathrm{d}{ }^{-1}$ and $4.2 \pm 1.5 \mu \mathrm{g} \mathrm{chl}$ $\mathrm{l}^{-1}$, respectively. These values are in reasonable agreement with the results from the present study. In this study, the rate at which IR approached $I_{\max }$ tended to increase with increasing food size (Table 2). This is also consistent with the results of $\mathrm{O}^{\prime}$ Connors et al. (1980).
Use of weight-specific IR alone would have led to the conclusion that there was little relationship between IR and algal concentration. However, the multivariate regression analysis showed that both GPC and IR were more susceptible to changes in food concentration than to changes in body size (Table 4; Dam 1989). Other investigators have also shown that the use of ratios to scale data for differences in body size can lead to erroneous conclusions (Gonor 1972, Atchley 1978. Blem 1984, Reist 1985). Forming ratios is adequate for scaling data when the variable of interest varies isometrically (a straight relationship with an intercept of zero) rather than allometrically (a curvilinear relationship or one with an intercept different from zero) with body size (Packard \& Boardman 1987). This condition was not met in the present study. Therefore, the use of a ratio (weight-specific IR) in this study would have been unjustified. We suggest that in order to assess the relative contribution of food concentration and body size to seasonal changes in GPC and IR, a multivariate analysis is a more appropriate tool. Packard \& Boardman (1987) also advise researchers to use an analysis of covariance rather than weight-specific indices when size may be a confounding variable.

The above discussion does not suggest that body size does not influence GPC or IR of copepods. The effect of body size on these parameters has been documented (references in Peters \& Downing 1984, Morales et al. 1990). Instead, we argue that changes in GPC and IR of Temora longicornis did not merely reflect changes in body size. In our study, the relationship between IR and body size was not strong, probably because, as the season progressed, the possible decrease in IR associ- 
ated with decrease in body size was balanced by the increase in IR associated with increasing temperature.

In Long Island Sound, temperature is negatively correlated with Temora longicornis body size and with chlorophyll concentration. Thus, isolating the effect of temperature on GPC and IR in a field study such as this is difficult. However, the apparent negative effect of temperature on GPC revealed by the multivariate analysis poses an interesting question - is the negative effect of temperature on GPC due to a more pronounced influence of temperature on gut evacuation rate $(K)$ than on ingestion rate? I.e., assuming that IR = $K \times \mathrm{GPC}$ then at a given temperature, GPC will be determined by the ratio of $\mathrm{IR} / K$. If $K$ increases with temperature faster than IR, GPC will decrease with increasing temperature. The only study that has investigated the influence of temperature simultaneously on IR and $K$ is that of Kiørboe et al. (1982). They found that temperature had a slightly greater effect on IR $\left(Q_{10}=\right.$ $3.9)$ than on $K\left(Q_{10}=3.3\right)$. Assuming that these values apply to $T$. longicornis, one would then predict that GPC would increase with temperature. This prediction was not borne out in the present study. One possibility is that the results of Kiørboe et al. (1982) do not apply to $T$. longicornis. Another possibility is that, as suggested in the 'Results' section, the apparent negative effect of temperature on GPC may reflect negative covariability of temperature and chlorophyll concentration.

This study examines a simple approach into trying to elucidate how and why the in situ herbivorous feeding behavior of copepods varies on a seasonal scale. It was logical first to examine the relationships between changes in algal concentration and size and changes in ingestion rates, then to ask how these relationships may be affected by changes in body size of the grazers throughout their growth season. It is clear that factors other than algal concentration and size, and the size of the grazers, need to be invoked in order to account for the 30 to $40 \%$ of unexplained variance in ingestion rates of Temora Iongicornis. Part of the variance unaccounted for may be related to the broad degree of omnivory characteristic of this copepod (review in Turner 1984), which would tend to obscure the relationship between IR and phytoplankton concentration and size alone. Furthermore, recent studies point to the importance of food quality in affecting ingestion of food particles (e.g. Huntley et al. 1983, DeMott 1986, Gill \& Harris 1987). For example, it is possible that the very high ingestion rates of $T$. longicornis from late June to early July 1986, despite the relatively low concentration of large-sized phytoplankton and the small size of females at this time, were related to the rapid rates of phytoplankton growth at this time (e.g. Cowles et al. 1988). Houde \& Roman (1987), Cowles et al. (1988), Butler et al. (1989) and Kiørboe (1989) have shown that cellular protein and nitrogen content are important in regulating ingestion rates of copepods. Further advances in our understanding of the in situ feeding behavior of herbivorous zooplankton may be achieved by studies which include additional indices of food quality such as C:N, protein cell ${ }^{-1}$ or nitrogen cell ${ }^{-1}$ to complement measurements of chlorophyll concentration in different size fractions.

Acknowledgements. We thank Drs M. Dagg, S. Smith, D Lonsdale, M. Roman, T. Kiørboe and 2 anonymous reviewers for comments and suggestions that improved the quality of this paper. We thank D. Bellantoni, T. Johnson and S. Hornigan for help during the cruises. Research supported by Grant NA86AADSG045 from New York Sea Grant Institute, awarded to W. T. Peterson, and by Grants-in-Aid of Research from the Lemer-Gray Fund for Marine Research of the American Museum of Natural History and Sigma Xi Foundation, awarded to H. G. Dam. This paper was written while H. Dam held a postdoctoral appointment at Horn Point Laboratory. This is contribution 789 of MSRC, SUNY at Stony Brook, and 2201 of CEES, University of Maryland System.

\section{LITERATURE CITED}

Atchley, W. R. (1978). Ratios, regression intercepts and the scaling of data. Syst. Zool. 27: 78-83

Baars, M. A., Oosterhuis, S. S. (1984). Diurnal feeding rhythms in North Sea copepods measured by gut fluorescence, digestive enzyme activity and grazing on labelled food. Neth. J. Sea Res. 18: 120-142

Bartram, W. C. (1980). Experimental development of a model for the feeding of neritic copepods on phytoplankton. J. Plankton Res. 3: 25-51

Bellantoni, D. C., Peterson, W. T (1987). Temporal variability in egg production rates of Acartia tonsa Dana in Long Island Sound. J. exp. mar. Biol. Ecol. 107: 199-208

Berggreen, U., Hansen, B., Kiørboe, T. (1988). Food size spectra, ingestion and growth of the copepod Acartia tonsa during development: implications for determination of copepod production. Mar. Biol. 99: 341-352

Blem, C. R. (1984). Ratios in avian physiology. Auk 101: $153-155$

Butler, N. M., Suttle, C. A., Neill, W. E. (1989). Discrimination by freshwater zooplankton between algal cells differing in nutritional status. Oecologia 78: 368-372

Capriulo, G. M., Carpenter, E. J. (1983). Abundance, species composition and feeding impact of tintinnid microzooplankton in Central Long Island Sound. Mar. Ecol. Prog. Ser. 10: $277-288$

Conover, S. A. M. (1956). Oceanography of Long Island Sound, 1952-1954 IV Phytoplankton. Bull. Bingham oceanogr. Coll. 15: 62-112

Cowles, T J., Olson, R. J., Chisholm, S. W (1988). Food selection by copepods: discrimination on the basis of food quality. Mar. Biol. 100: 41-49

Dagg, M. J., Turner, J. T (1982). The impact of copepod grazing on the phytoplankton of Georges Bank and the New York Bight. Can. J. Fish. Aquat. Sci. 39: 979-990

Dam, H. G. (1986). Short term feeding of Temora longicornis Müller in the laboratory and the field. J. exp. mar. Biol. Ecol. 99: 149-161

Dam, H. G. (1989). The dynamics of copepod grazing in Long Island Sound. Ph.D. dissertation, State University of New York at Stony Brook, New York 
Dam, H. G., Peterson, W. T. (1988). The effect of temperature on the gut clearance rate constant of planktonic copepods. J. exp. mar. Biol. Ecol. 123: 1-14

Deevey, G. B. (1960). Relative effects of temperature and food on seasonal variations in length of marine copepods in some eastern American and western European waters. Bull. Bingham oceanogr. Coll. 17: 54-85

DeMott, W. R. (1986). The role of taste in food selection by freshwater zooplankton. Oecologia 69: 334-340

Durbin, E. G., Durbin, A. G., Smayda, T J., Verity, P. G. (1983). Food limitation of production by adult Acartia tonsa in Narragansett Bay, Rhode Island. Limnol. Oceanogr. 28: $1199-1213$

Frost, B. W. (1972). Effects of size and concentration of food particles on the feeding behavior of the marine planktonic copepod Calanus pacificus. Limnol. Oceanogr. 8: 805-815

Gill, C. W., Harris, R. P. (1987). Behavioural responses of the copepods Calanus helgolandicus and Temora longicornis to dinoflagellate diets. J. mar. biol. Ass. U.K. 67: 785-801

Gonor, J. J. (1972). Gonad growth in the sea urchin, Strongylocentratus purpuratus (Stimpson) (Echinodemata: Echinoidea) and the assumptions of gonad index methods. J. exp. mar. Biol. Ecol. 10; 89-103

Head, E. J. H., Wang, R., Conover, R. (1984). Comparison of diurnal feeding rhythms in Temora longicornis and Centropages hamatus with digestive enzyme activity. J. Plankton Res. 6: 543-551

Houde, S. E. L., Roman, M. R. (1987). Effects of food quality on the functional ingestion response of the copepod Acartia tonsa. Mar. Ecol. Prog. Ser. 40: 69-77

Huntley, M. E., Barthel, K. G., Star, J. L. (1983). Particle rejection by Calanus pacificus: discrimination between similarly sized particles. Mar. Biol. 74: 151-160

Kiørboe, T. (1989). Phytoplankton growth rate and nitrogen content: implications for feeding and fecundity in a herbivorous copepod. Mar. Ecol. Prog. Ser. 55: 229-234

Kiørboe, T., Møhlenberg, F., Nicolajsen, H. (1982). Ingestion rate and gut clearance in the planktonic copepod Centropages hamatus (Lilljeborg) in relation to food concentration and temperature. Ophelia 21: 181-194

Kiørboe, T., Møhlenberg, F., Riisgård, H. U. (1985). In situ feeding rates of planktonic copepods: a comparison of four methods. J. exp. mar. Biol. Ecol. 88: 67-81

Malone, T C., Chervin, M. B. (1979). The production and fate of phytoplankton size fractions in the plume of the Hudson River, New York Bight. Limnol. Oceanogr. 24: 683-696

Mayzaud, P., Poulet, S. A. (1978). The importance of the time factor in the response of zooplankton to varying concentrations of naturally occurring particulate matter. Limnol. Oceanogr. 23: 1144-1154

Morales, C. E., Bautista, B., Harris, R. P. (1990). Estimates of ingestion in copepod assemblages: gut fluorescence in relation to body size. In: Barnes, M., Gibson, R. N. (eds.) Trophic relationships in the marine environment. Proc. 24 th Eur. mar. Biol. Symp. Aberdeen University Press, p. 565-577

Nicolajsen, H., Møhlenberg, F., Kiørboe, T. (1983). Algal grazing by the planktonic copepods Centropages hamatus and Pseudocalanus sp. Diurnal and seasonal variation during the spring phytoplankton bloom in the Øresund. Ophelia 22: $15-31$

This article was presented by $T$. Kiorboe, Charlottenlund, Denmark
Nival, P., Nival, S. (1976). Particle retention of a herbivorous copepod, Acartia clausi (adults and copepodite stages): effects on grazing. Limnol. Oceanogr. 21: 24-28

O'Connors, H. B. Jr, Biggs, D. C., Ninivaggi, D. V. (1980). Particle-size-dependent maximum grazing rates for Temora longicornis fed natural particle assemblages. Mar. Biol. 56: $65-70$

Packard, G. C., Boardman, T J. (1987). The misuse of ratios to scale physiological data that vary allometrically with size. In: Feder, M. A., Huey, R. B. (eds.) New directions in ecological physiology. Cambridge University Press, Cambridge, p. 216-239

Parsons, T. R., LeBrasseur, R. J., Fulton, J. D. (1967). Some observations on the dependence of zooplankton grazing on the cell size and concentration of phytoplankton blooms. J. oceanogr. Soc. Japan 23: 10-17

Peters, R. H., Downing, J. A. (1984). Empirical analysis of zooplankton filtering and feeding rates. Limnol. Oceanogr. 29: 763-784

Peterson, W. T. (1985). Abundance, age structure and in situ egg production rates of the copepod Temora longicornis in Long Island Sound, New York. Bull. mar. Sci. 37: $726-738$

Peterson, W. T. (1986). The effect of seasonal variations in stratification on plankton dynamics in Long Island Sound. In: Bowman, M. J., Yentsch, C. M., Peterson, W. T. (eds.) Tidal mixing and plankton dynamics. Lecture notes on coastal and estuarine studies 17 . Springer-Verlag, New York, p. 297-320

Peterson, W. T., Bellantoni, D. C. (1987). Relationships between water column stratification, phytoplankton cell size and copepod fecundity in Long Island Sound and off central Chile. S. Afr. J. mar. Sci. 5: 411-421

Poulet, S. A. (1978). Comparison between five coexisting species of marine copepods feeding on naturally occurring particulate matter. Limnol. Oceanogr. 23: 1126-1143

Price, H. J., Paffenhöfer, G.-A. (1985). Perception of food availability by calanoid copepods. Arch. Hydrobiol. (Beih. Ergebn. Limnol.) 21: 115-124

Price, H. J., Paffenhöfer, G.-A., Strickler, J. R. (1983). Modes of cell capture in calanoid copepods. Limnol. Oceanogr. 28: $116-123$

Reist, J. D. (1985). An empirical evaluation of several univariate methods that adjust for size variation in morphometric data. Can. J. Zool. 63: 1429-1439

Runge, J., Ohman, M. D. (1982). Size fractionation of phytoplankton as an estimate of food available to herbivores. Limnol. Oceanogr. 27: 570-576

Sokal, R. R., Rohlf, F. J. (1981). Biometry, 2nd edn. W. H. Freeman \& Co., San Francisco

Strathmann, R. R. (1967). Estimating the organic carbon content of phytoplankton from cell volume or plasma volume. Limnol. Oceanogr. 12: 411-418

Tiselius, P. (1988). Effects of diurnal feeding rhythms, species composition and vertical migration on the grazing impact of calanoid copepods in the Skagerrak and Kattegat. Ophelia 28: 215-230

Turner, J. T. (1984). The feeding ecology of some zooplankters that are important prey items of larval fish. NOAA natn. mar. Fish. Serv. Tech. Rep. 7: 1-28

Manuscript first received: October 25, 1989

Revised version accepted: January 25, 1991 